Fakultas Hukum, Universitas Lampung, Bandar Lampung, Lampung, Indonesia. http://jurnal.fh.unila.ac.id/index.php/corruptio

Volume 01 Issue 1, January - June 2020. PP: 27-36

P-ISSN: 2723-2573

E-ISSN: 2745-9276

\title{
Peradilan In Absentia Pada Perkara Tindak Pidana Korupsi
}

\author{
In Absentia Judiciary in Corruption Crime Cases
}

\author{
P. Iskandar Welang \\ dmeilia40@gmail.com \\ Fakultas Hukum Universitas Lampung
}

Submitted: Feb 28, 2020; Reviewed: Mar 16, 2020; Accepted: Apr 20, 2020

\begin{tabular}{|c|c|}
\hline Info Artikel & Abstrak \\
\hline $\begin{array}{l}\text { Kata Kunci: In Absentia; Tindak Pidana; } \\
\text { Korupsi. } \\
\text { Keywords: In Absentia; Criminal Acts; } \\
\text { Corruption }\end{array}$ & $\begin{array}{l}\text { Peradilan Tindak Pidana Korupsi dengan } \\
\text { cara in absentia merupakan suatu } \\
\text { penyimpangan an tau serlarang } \\
\text { dikarenakan dianggap sebagai } \\
\text { pelanggaran hak asasi terdakwa sehingga } \\
\text { menyebabkan hak bagi terdakwa untuk } \\
\text { melakukan suatu pembelaan akan hilang } \\
\text { atau terabaikan sebagaimana diatur } \\
\text { dalam Pasal } 196 \text { Ayat (1) KUHAP. } \\
\text { Peradilan dengan cara in absentia hanya } \\
\text { diperbolehkan untuk pelaku pelanggaran } \\
\text { lalu lintas saja. Lalu bagaimana } \\
\text { seandainya peradilan dengan cara in } \\
\text { absentia diterapkan pada perkara tindak } \\
\text { pidana korupsi. Metode dalam penelitian } \\
\text { ini menggunakan pendekatan yang } \\
\text { meliputi pendekatan empiris yang } \\
\text { dilakukan melalui penelitian langsung di } \\
\text { lapangan, dan pendekatan normatif yang } \\
\text { dilakukan melalui studi kepustakaan } \\
\text { terkait dengan perundang-undangan, } \\
\text { hasil penelitian dan literatur lainnya. } \\
\text { Pada pelaksanaannya peradilan dengan }\end{array}$ \\
\hline
\end{tabular}


cara in absentia untuk perkara korupsi tidak melanggar hak-hak tersangka karena kepada terdakwa tetap diberikan haknya untuk mengikuti tahapan demi peradilan pidana baik sejak proses penyelidikan, penyidikan dan persidangan, akan tetapi dalam hal ini terdakwa tidak mau menggunakan atau memanfaatkan hak-haknya yang telah diberikan dan dijamin peraturan perundang-undangan sebagaimana yang diatur dalam KUHAP.

Abstract
Corruption Criminal Court in
absentia is a deviation or prohibited
because it is considered as a violation of
the defendant's human rights so that the
right of the defendant to make a defense
will be lost or ignored as regulated in
Article 196 Paragraph (1) of the
Criminal Procedure Code. Judgment in
absentia is only permitted for
perpetrators of traffic violations. Then
what if the court in absentia is applied to
corruption cases. The method in this
research uses an approach that includes
an empirical approach carried out
through direct research in the field, and
a normative approach carried out
through literature studies related to
legislation, research results and other
literature. In the implementation of the
court in absentia for corruption cases do
not violate the rights of the suspect
because the defendant is still given the
right to follow the stages for criminal
justice both from the process of
investigation, investigation and trial, but
in this case the defendant does not want
to use or utilize the rights their rights
which have been granted and guaranteed
by laws and regulations as regulated in
the Criminal Procedure Code.




\section{A. Pendahuluan}

In absentia bukan merupakan sistem peradilan. Menurut Kamus Besar Bahasa Indonesia, in absentia diartikan sebagai suatu keadaan tidak hadir. Berdasarkan hal tersebut in absentia bukanlah merupakan salah satu jenis peradilan akan tetapi kondisi dalam suatu persidangan dimana terdakwa dalam hal ini tidak menggunakan haknya untuk hadir dalam tahapan peradilan pidana. Salah satu cara yang dilakukan secara luar biasa adalah dapat dilangsungkannya pemeriksaan perkara korupsi tanpa dihadiri oleh terdakwa (in absentia). ${ }^{1}$ Penyelesaian suatu perkara hendaknya menghadirkan si terdakwa, namun dalam peradilan in absentia menghendaki penyelesaian perkara khususnya perkara Tindak Pidana Korupsi, Tindak Pidana Terorisme, dan dalam Tindak Pidana Pencucian Uang dapat di lakukan meski tanpa kehadiran terdakwa. ${ }^{2}$ Pada asasnya yang dapat melakukan tindak pidana adalah manusia (naturlijk persoon). Hal ini dapat disimpulkan dari rumusan tindak pidana dalam undangundang yang selalu dimulai dengan kata "barangsiapa" yang tidak dapat diartikan lain selain orang (manusia). ${ }^{3}$ Dalam praktek peradilan pidana biasanya yang banyak terlibat adalah yang berkaitan dengan jabatan publik atau jabatan pemerintahan. ${ }^{4}$ Suatu perkara tindak pidana korupsi yang terdakwanya tidak diketahui keberadaannya, akan diminta oleh Penuntut Umum untuk disidangkan secara in absentia (tanpa hadirnya terdakwa). ${ }^{5}$ Yang dimaksud tidak hadir adalah sipelaku melakukan perbuatan atau tindakan meninggalkan atau menjauhkan diri atau tidak berada ditempat yang telah ditentukan baginya untuk melaksanakan dinas/kewajiban tugasnya, adapun yang dimaksud tempat tugas Terdakwa dalam perkara ini adalah satuan terakhir Terdakwa. ${ }^{6}$ Korupsi dan pemberantasannya di Indonesia memang rumit, masalahnya tidak hanya di pemerintah pusat, tetapi juga mengarah ke daerah-daerah. ${ }^{7}$ Persidangan in absentia yang dirumuskan di dalam Peraturan Mahkamah Agung tidak melakukan pemanggilan sebelumnya kepada para pelanggar untuk menghadiri persidangan, hakim. ${ }^{8}$

Tindak pidana korupsi di Indonesia penyebarannya telah meluas dalam masyarakat. Perkembangannya terus meningkat dari tahun ke tahun, baik jumlah kasus yang terjadi dan jumlah kerugian keuangan negara maupun dari segi kualitas tindak pidana yang dilakukan semakin sistematis serta lingkupnya sudah memasuki seluruh aspek kehidupan masyarakat. ${ }^{9}$ Landasan seseorang melakukan mkorupsi biasanya adalah Kekuasaan merupakan kekuatan untuk mengatur suatu objek sesuai dengan kehendaknya. Kekuasaan dalam konteks pemerintahan bukan hanya sekedar bentuk hubungan tertentu antar manusia, bukan juga suatu

\footnotetext{
${ }^{1}$ Suriady Harianja, "Peradilan In Absentia Pada Perkara Tindak Pidana Korupsi Dalam Perspektif HAM Terdakwa," UNNES Law Journal. Vol. 2, no. 1 (2013): 36-43 https://journal.unnes.ac.id/sju/index.php/ulj/article/view/2903/2686. hlm 36.

${ }^{2}$ Arly, and Y Mangoli, "Eksistensi Peradilan In Absentia Dalam Hukum Acara Pidana Di Indonesia Menurut Kuhap," LEX CRIMEN, vol. 5, no. 3 (April 7, 2016): 66-74, https://ejournal.unsrat.ac.id/index.php/lexcrimen/article/view/11682. hlm 66.

${ }^{3}$ Budi A Suhariyanto Pusat Penelitian dan Pengembangan Hukum dan Peradilan MA-RI J1 Jend Yani Kav and Cempaka Putih Timur Jakarta, "Progressivity of Criminal Decision on Corporate Actors Corruption," Disetujui Diterbitkan, vol. 16, (June 1, 2016): 201-213, https://ejournal.balitbangham.go.id/index.php/dejure/article/view/58. hlm 240.

${ }^{4}$ Mohammad Sahlan et al., "Unsur Menyalahgunakan Kewenangan," Jurnal Hukum IUS QUIA IUSTUM. Vol. 23, no. 2 (October 17, 2016): 193-271, https://journal.uii.ac.id/IUSTUM/article/view/6583/5934. hlm 279.

5 Ardhyansah, "Penyidikan In Absentia Dalam Penanganan Tindak Pidana Korupsi Di Indonesia (Sebuah Alternatif Penerapan Asas Peradilan Cepat)." Jurnal Idea Hukum. Vol. 6, no. 1 (2020): 114-130, http://www.jih.fh.unsoed.ac.id/index.php/jih/article/view/135/115. hlm 119.

${ }^{6}$ Utomo, "Pembuktian Dakwaan Oditur Militer Dalam Pemeriksaan Secara In Absentia Pada Persidangan Perkara Desersi Di Masa Damai." Verstek. Vol. 4, no 2 (2016): 146-156, https://jurnal.uns.ac.id/verstek/article/view/38387/25424. hlm 151.

${ }^{7}$ Olan Laurance Hasiholan Pasaribu, Iman Jauhari, and Elvi Zahara Lubis, "KAJIAN YURIDIS TERHADAP PUTUSAN BEBAS TINDAK PIDANA KORUPSI (Studi Kasus Pada Pengadilan Negeri Medan)," JURNAL MERCATORIA, vol. 1, no. 2 (2008): 130-140, http://ojs.uma.ac.id/index.php/mercatoria/article/view/627. hlm 132.

${ }^{8}$ Haklainul Dunggio, Bambang Sugiri, and Rachmad Syafa'at, "Peradilan In Absentia Bagi Pelanggar Lalu Lintas Yang Berkeadilan The Justice Of In Absentia Judicatory For Traffic Offender," Jurnal Ilmiah Pendidikan Pancasila Dan Kewarganegaraan. Vol. 4, no. 2 (January 6, 2020): 259-268, http://journal2.um.ac.id/index.php/jppk. hlm 261.

9 Bram Mohammad Yasser, "Pengujian Unsur Penyalahgunaan Wewenang Pada Peradilan Tata Usaha Negara Dalam Kaitannya Dengan Tindak Pidana Korupsi," Soumatera Law Review 2, no. 1 (May 1, 2019): 1-24, http://ejournal.lldikti10.id/index.php/soumlaw/article/view/3558/1353 https://doi.org/10.22216/soumlaw.v2i1.3558.g1352. hlm 2.
} 
gejala kehidupan bermasyarakat yang tidak ada sangkut pautnya dengan alam, melainkan sama dengan semua dimensi sosial dan dimensi alamiah lainnya. ${ }^{10}$ Sistem peradilan pidana (Criminal Justice System) sebagai suatu sistem dalam penegakan hukum pidana berupaya untuk menanggulangi masalah kejahatan dimaknai sebagai upaya untuk mengendalikan atau membatasi kejahatan agar berada dalam batas-batas toleransi masyarakat. ${ }^{11}$ Pemeriksaan tanpa hadirnya Terdakwa dalam pengertian in absentia adalah pemeriksaan yang dilaksanakan supaya perkara tersebut dapat diselesaikan dengan cepat demi tetap tegaknya suatu keadilan. ${ }^{12}$ Adanya kerugian negara sudah cukup untuk menjerat pelaku korupsi. ${ }^{13}$ Cara in absentia dalam peradilan pidana merupakan suatu penyimpangan atau terlarang dikarenakan dianggap sebagai pelanggaran hak asasi terdakwa sehingga menebabkan hak bagi terdakwa untuk melalukan suatu pembelaan akan hilang atau terabaikan. Peradilan in absentia dalam perkara Tindak Pidana Korupsi sebagaimana yang dimaksud dalam peraturan perundangundangan yang ada sekarang ini. ${ }^{14}$ Peradilan in absentia bertentangan dengan proses persidangan umum sebagaimana diatur dalam Pasal 196 Ayat (1) KUHAP. Pada pasal tersebut diatur bahwa "Pengadilan memutus perkara dengan hadirnya terdakwa kecuali dalam hal undang-undang ini menentukan lain".

Berdasarkan ketentuan di atas maka sebenarnya peradilan in absentia diperbolehkan namun hanya untuk pelaku yang menyalahi atau melakukan tindakan yang melanggar praturan lalu lintas dimana Pasal 213 KUHAP mengatur bahwa "terdakwa dapat menunjuk seorang dengan surat untuk mewakilinya di sidang”. Selanjutnya pada Pasal 214 Ayat (1) dan ayat (2) KUHAP diatur bahwa:

1) Jika terdakwa atau wakilnya tidak hadir di sidang, pemeriksaan perkara dilanjutkan.

2) Dalam hal putusan diucapkan di luar hadirnya terdakwa, surat amar putusan segera disampaikan kepada terpidana;

Prinsipnya sesuai dengan peraturan di atas, peradilan yang dilakukan dengan cara in absentia dibenarkan akan tetapi hanya untuk pelanggaran lalu lintas saja. Menjadi suatu pertanyaan bagaimana seandainya peradilan dengan cara in absentia ini diberlakukan untuk perkara di luar atau selain pelanggaran lalu lintas.

Peradilan in absentia yang pada awalnya hanya dibenarkan untuk pelanggaran lalu lintas saja kemudian berubah untuk perkara tindak pidana ringan sebagaimana Mahkamah Agung melalui Surat Edaran Mahkamah Agung No. 9 Tahun 1985 tentang Putusan yang Diucapkan di Luar Hadirnya Terdakwa telah pula memperluas pelaksanaan persidangan secara in absentia. Perluasan ini bertujuan untuk mempercepat pelaksanaan Acara Pemeriksaan Cepat dengan memutuskan suatu perkara khususnya tindak pidana ringan dan pelanggaran lalu lintas tanpa kehadiran terdakwa. Pemeriksaan dan putusan secara In Absentia juga bersesuaian dengan Pasal 12 ayat 1 dan 2 undang-undang republik indonesia nomor 48 Tahun 2009 Tentang kekuasaan kehakiman , dimana dalam Pasal tersebut menentukan bahwa Pengadilan

\footnotetext{
${ }^{10}$ Shandi Patria Airlangga, "Hakikat Penguasa Dalam Negara Hukum Demokratis The Nature Of The Authorities In A Democratic Rule Of Law,” Cepalo 3, no. 1 (September 17, 2019): 1-10, https://doi.org/10.25041/cepalo.v3no1.1783. hlm 3.

${ }^{11}$ Sahuri Lasmadi and M Hum, "Tumpang Tindih Kewenangan Penyidikan Pada Tindak Pidana Korupsi Dalam Perspektif Sistem Peradilan Pidana," INOVATIF | Jurnal Ilmu Hukum, vol. 2, no. 3 (2010): 33-43, https://onlinejournal.unja.ac.id/jimih/article/view/200. hlm 34.

${ }_{12}$ Mohammad Ali Fikri and Pudji Astuti, "Analisis Yuridis Penyelesaian Perkara Disersi Yang Diputus Secara In Absentia Sebelum Jangka Waktu 6 Bulan (Studi Kasus Di Pengadilan Militer Iii-12 Surabaya),” JURNAL NOVUM. Vol. 4, no. 4 (October 15, 2017): 1-7, http://www.dilmil-surabaya.go.id. hlm 4.

${ }_{13}$ Hafidz, "Sistem Pertanggungjawaban Perkara Korupsi Dalam Rangka Percepatan Penyelamatan Uang Negara." Jurnal Dinamika Hukum. Vol. 11, (2011): 130-145 , http://dinamikahukum.fh.unsoed.ac.id/index.php/JDH/article/view/269/261. hlm 124-134. hlm 133.

14 Zul Akli, "Peradilan In Absentia Terhadap Terdakwa Yang Belum Di-Periksa Pada Tingkat Penyidikan Dalam Perkara Tindak Pi-Dana Korupsi," REUSAM- Jurnal Ilmu Hukum, vol. 8, (May 13, 2020): 52-68, https://ojs.unimal.ac.id/index.php/reusam/article/view/2613. hlm 53.
} 
memutus ataupun memeriksa perkara Pidana dengan kehadiran pelaku kecuali kalau Undangundang berkata lain. ${ }^{15}$

Bagaimana apabila peradilan yang dilakukan dengan menggunakan cara in absentia diterapkan pada perkara tindak pidana korupsi? Pertanyaan tersebut sangat menarik untuk dikaji. Di Indonesia sendiri terkait dengan peradilan Surat Edaran Mahkamah Agung No. 9 Tahun 1985 tentang Putusan yang Diucapkan di Luar Hadirnya Terdakwa. Selanjutnya untuk perkara tindak pidana korupsi diatur dalam Pasal 38 Ayat (1) Undang-Undang Nomor 31 Tahun 1999 sebagaimana yang telah diubah dengan Undang-Undang Nomor 20 Tahun 2001, yang mengatur bahwa "Dalam hal terdakwa telah dipanggil secara sah, dan tidak hadir di sidang pengadilan tanpa alasan yang sah, maka perkara dapat diperiksa dan diputus tanpa kehadirannyaSalah satu yurisprudensi untuk peradilan terhadap perkara tindak pidana korupsi adalah Putusan di Pengadilan Negeri Jakarta Selatan Nomor 1032/PID.B/2001/PN.JKT. PST tanggal 22 Maret 2002 putusan in absentia untuk menyelamatkan keuangan negara. ${ }^{16}$

Berdasarkan uraian tersebut di atas, maka penelitian ini akan difokuskan mengenai pembahasan Putusan Nomor 46/Pid-Sus-TPK/2016/ PN.Tjk yang merupakan putusan in absentia terhadap perkara tindak pidana korupsi. Terkait apa yang telah diuraikan di atas, penulis tertarik untuk mengadakan suatu penelitian atau bahasan mengenai implementasi peradilan dengan cara in absentia dan mengapa peradilan dengan cara in absentia digunakan untuk penangan suatu perkara tindak pidana korupsi. Adapun sebagai data penelitian yang digunakan merupakan data pada tahun 2016-2017 khusus pada Putusan Nomor 46/Pid-SusTPK/2016/PN.Tjk, dengan menggunakan metode pendekatan yuridis normatif berupa studi kepustakaan dan atau doktrinal berupa mengumpulkan data-data seperti teori-teori, konsepkonsep, serta perundang-undangan yang berkaitan dengan permasalahan. Pendekatan selanjutnya yaitu pendekatan yuridis normatif yang dilakukan dengan cara penelitian secara langsung ke tempat penelitian dan pihak terkait yang dilakukan melalui wawancara dengan para narasumber.

\section{B. Pembahasan}

\section{Implementasi Peradilan In Absentia Pada Perkara Tindak Pidana Korupsi}

Berdasarkan ketentuan pada Pasal 284 Ayat (2) KUHAP bahwa pada intinya semua perkara pidana harus sesuai dengan KUHAP namun ada pengecualian terhadap hal khusus yang kemudian diatur dengan undang-undang khusus tertentu. Hal ini dapat diartikan bahwa hukum di Indonesia tidak membenarkan proses peradilan dengan cara in absentia, dikarenakan terdakwa yang tidak hadir dalam persidangan, maka pemeriksaan perkara tidak dapat dilakukan, akan tetapi peruntukan peradilan in absentia yang pada awalnya hanya untuk perkara pelanggaran lalu lintas kemudian diperluas untuk perkara tindak pidana ringan saja menjadi dapat digunakan untuk perkara tindak pidana korupsi sejak dikeluarkannya UndangUndang Nomor 31 Tahun 1999.

Dalam hal terdakwa telah dipanggil secara sah, dan tidak hadir di sidang pengadilan tanpa alasan yang sah, maka perkara dapat diperiksa dan diputus tanpa kehadirannya (Pasal 38 Ayat (1) Undang-Undang Nomor 31 Tahun 1999 sebagaimana yang telah diubah dengan Undang-Undang Nomor 20 Tahun 2001.

\footnotetext{
15 A Made Yuda Dwi Hendrata, A A Sagung Laksmi Dewi Dan I Nengah Laba, "Persidangan in Absentia Terhadap Tindak Pidana Korupsi (Studi Putusan Nomor: 13/Pid-Sus-Tpk/2017/Pn Mtr)." Jurnal Analogi Hukum. Vol. 1, no. 1 (December 17, 2019): $1-5$, https://www.ejournal.warmadewa.ac.id/index.php/analogihukum/article/view/1448. hlm 2.

${ }^{16}$ Irma Sukardi. Bantuan Timbal Balik dalam Masalah Pidana (Mutual Legal Assistance) dalam Perampasan Aset Tindak Pidana Korupsi Berdasarkan Undang-Undang Nomor 1 Tahun 2006 tentang Bantuan Timbal Balik dalam Masalah Pidana. Tesis Pasca FH UI, Jakarta, 2012, hlm. 76.
} 
Pada penelitian ini penulis memfokuskan pada Putusan Nomor 46/Pid-SusTPK/2016/PN.Tjk yang merupakan putusan in absentia terhadap perkara tindak pidana korupsi. Berdasarkan keterangan Dina Safitri ${ }^{17}$ sebagai Jaksa pada Kejaksaan Negeri Metro dalam perkara No. REG.PERK:PDS-03/N.8.12/11/2016 tentang dugaan Tindak Pidana Korupsi pembangunan ruang kelas SMAN 6 Kota Metro dengan kerugian keuangan negara berdasarkan hasil pemeriksaan atau audit yang dilakukan oleh BPKP Provinsi Lampung sebesar Rp. 54.144.066,35 (lima puluh empat juta seratus empat puluh empat ribu enam puluh enam rupaiah tiga puluhg lima sen) dengan tersangka Abdul Mukti, bahwa kesulitan-kesulitan terkait denganpelaksanaan peradilan in absentia seperti pada tahapan penyidikan adalah sebagai berikut:

a. Aparat penegak hukum baik Kepolisian maupun Kejaksaan kesulitan dalam hal pengumpulan alat bukti.

b. Aparat penegak hukum baik Kepolisian maupun Kejaksaan kesulitan dalam hal melakukan penyitaan aset pelaku tindak pidana korupsi yang dikarenakan pelaku tindak pidana korupsi pada umumnya mempunyai aset yang dari awal telah dialih namakan atas nama orang lain atau pelaku telah melarikan diri keluar negeri.

Selanjutnya dalam proses persidangan kasus tersebut di atas berdasarkan putusan Nomor 46/Pid-Sus-TPK/2016/PN.Tjk, Firza Andriansyah ${ }^{18}$, hakim Pengadilan TIPIKOR pada Pengadilan Negeri Tanjungkarang dan selaku hakim ketua dalam perkara tersebut di atas, mengemukakan bahwa permasalahan yang dihadapi adalah:

a. Saksi memberikan keterangan yang berbeda-beda.

b. Jumlah barang bukti yang disita dari terdakwa pada praktiknya selalu ada perbedaan.

c. Uang pengganti kerugian Negara selalu tidak tercukupi dikarenakan barang bukti yang disita tidak mencukupi untuk mengganti kerugian keuangan negara yang ditimbulkan.

Pada tahap proses pemeriksaan di pengadilan, terdakwa kasus tersebut berhalangan hadir sehingga ketidakhadiran terdakwa pada tahap pemeriksaan pengadilan sebenarnya sangat merugikan dirinya sendiri. Ketidakhadiran terdakwa menyebabkan hilangnya haknya untuk pembelaan dimuka pengadilan, namun hal ini di karena kesalahan terdakwa sendiri yang tidak menggunakan haknya dengan tidak hadir pada proses pemeriksaan diperadilan tersebut. Ketidakhadiran terdakwa pada tahap pemeriksaan dimuka pengadilan bukan berarti hilangnya semua hak terdakwa pada proses pengadilan. Terdakwa masih dapat menggunakan haknya pada persidangan yang dilakukan dengan cara in absentia dengan meminta banding atau keberatan.

Pada praktik persidangan perkara tindak pidana korupsi dengan cara in absentia, tentunya tidak semudah sidang dengan acara biasa hal ini dikarenakan hakim kesulitas dalam mengambil keputusan karena harus menemukan kebenaran materill dan keyakinan bahwa terdakwa bersalah dengan memeriksa langsung terdakwa. Adapun kelemahan yang dihadapi hakim dalam menyidangkan perkara tindak pidana korupsi secara in absentia menurut Firza Andriansyah $^{19}$, selaku hakim Pengadilan Tindak Pidana Korupsi pada Pengadilan Negeri Tanjungkarang adalah data tidak riil atau sepihak sehingga klarifikasi yang dilakukan oleh hakim terhadap terdakwa hanya pembuktian sepihak karena ketidakhadiran terdakwa. Hakim dalam hal ini kesulitan dalam mendapatkan keyakinan bahwa terdakwa benar-benar bersalah sedangkan pidana materil adalah konkret sehingga jaksa harus mengajukan bukti kongkret seperti hasil audit dan lain-lain.

7 Wawancara di Kantor Kejaksaan Negeri Metro pada 20 November 2018

18 Wawancara di Pengadilan Negeri Tanjungkarang pada tanggal 5 Desember 2018

19 Ibid 
Menurut Dina Safitri ${ }^{20}$, Jaksa pada Kejaksaan Negeri Metro kelemahan dalam menyidangkan perkara dengan cara in absentia adalah pemeriksaan terhadap terdakwa tidak bisa dilakukan secara objektif karena dengan tidak hadirnya berarti terdakwa tidak bisa memberikan pendapat berupa bantahan atau klarifikasi terhadap keterangan saksi sehingga kebenaran materiil akan sulit dicapai atau tidak optimal. Selanjutnya Alingga Putra Suyitno selaku Jaksa pada Kejaksaan Negeri Metro, berpendapat bahwa kesulitan jaksa dalam menyidangkan dengan cara in absentia, lebih kepada non teknis seperti pemanggilan terdakwa melalui surat kabar sehingga membutuhkan biaya yang tidak sedikit.

Pengadilan adalah lembaga atau badan yang bertugas menerima, memeriksa, mengadili, dan menyelesaikan setiap perkara yang diajukan kepadanya. Dalam "mengadili dan menyelesaikan suatu perkara" itulah terletak proses pemberian keadilan yang dilakukan oleh hakim baik tunggal maupun majelis, oleh karena itu, hakim merupakan unsur yang sangat penting dalam penyelenggaraan pengadilan. ${ }^{21}$

Peradilan merupakan proses pemberi keadilan untuk para pencari keadilan melalui suatu lembaga yang disebut pengadilan. Pelaksanaan peradilan perkara tindak pidana korupsi yang dilakukan dengan cara in absentia dalam upaya pengembalian kerugian keuangan negara, menurut penulis adalah suatu terobosan guna mewujudkan peradilan cepat, tepat dan sederhana.

\section{Peradilan In Absentia Digunakan Untuk Penanganan Perkara Tindak Pidana Korupsi}

Hukum dalam bernegara dan bermasyarakat tentunya akan terus berubah dari waktu ke waktu mengikuti perkembangan jaman. Pada proses peradilan pidana yang salah satu unsurnya ada penegak hukum yang secara hukum dituntut pertanggungjawabannya atas tindakannya sebagai pelaksana hukum atau aturan yang berlaku. Selain itu juga para penegak hukum dituntut sebagai penampung perkembangan, perubahan dan aspirasi masyarakat dalam bernegara.

Konsep hukum merupakan suatu yang tidak muncul secara tiba-tiba, akan tetapi merupakan hasil dari suatu perkembangan, kebiasaan dan adat istiadat yang berlaku dalam masyarakat pada waktu yang tidak sebentar sehingga ada suatu keterkaitan atau hubungan timbal balik antara hukum dengan masyarakat.

Peradilan secara in absentia merupakan salah satu contoh bentuk perubahan dalam hukum dan masyarakat. Terkait dengan putusan pengadilan dalam Putusan Nomor 46/Pid-SusTPK/2016/PN.Tjk terdapat beberapa alasan hakim dalam memberikan keputusan yang dibacakan secara in absentia. Hal ini dikarenakan pemanggilan yang dilakukan secara sah terhadap terdakwa tidak dipenuhi atau dihadiri oleh terdakwa. Selanjutnya pada dikarenakan perkara tindak pidana korupsi merupakan tindak pidana khusus maka dalam penanganannya membutuhkan penyelesaian secara khusus. Tindakan khusus dibutuhkan untuk tidak menunda proses peradilan hanya untuk menanti kehadiran para terdakwa.Rasa keadilan masyarakat juga merupakan hal yang perlu diperhatikan. Hal ini menurut penulis bertujuan selain untuk pengembalian kerugian keuangan negara akibat perbuatan yang dilakukan oleh para terdakwa juga bertujuan untuk membuat suatu kepastian hukum sehingga tidak menimbulkan keresahan di masyarakat.

20 Wawancara di Kantor Kejaksaan Negeri Metro pada 20 November 2018

21 Mohammad Daud Ali. Hukum Islam: Pengantar Ilmu Hukum dan Tata Hukum Islam di Indonesia. PT Raja Grafindo Persada, Jakarta, 2000. Ed,6,Cet 9, hlm. 250. 
Rasa keadilan masyarakat atas penegakan hukum pada pelaku tindak pidana korupsi tentunya selain pengembalian kerugian Negara juga terkait dengan pemberian hukuman "badan" yang tepat untuk pelaku itu sendiri. Pertimbangan hakim memberikan keputusan yang dibacakan secara in absentia yaitu bahwa para terdakwa yang dipanggil secara sah sesuai dengan ketentuan pada Pasal 145, Pasal 146 Ayat (1), Pasal 153, dan Pasal 154 Ayat (1) KUHAP, tidak pernah hadir dengan tanpa keterangan. Ketidakhadiran terdakwa di sidang pengadilan berlangsung sebagai berikut:

a. Tidak hanya sekali, namun dilakukan terdakwa secara terus menerus atau tidak pernah hadir sama sekali pada persidangan, sejak sidang pengadilan dibuka dan dinyatakan terbuka untuk umum oleh hakim sampai dengan ketika hakim menjatuhkan putusannya dalam perkaranya;

b. Dilakukan dalam satu atau beberapa kali diantara persidangan dalam arti terdakwa pernah menghadiri persidangan sejak sidang dibuka dan dinyatakan terbuka untuk umum oleh hakim sampai dengan hakim menjatuhkan putusannya dalam perkaranya.

Pada sidang pengadilan perkara tindak pidana korupsi sesuai dengan Pasal 38 Ayat (1) Undang-Undang Nomor 31 Tahun 1999 sebagimana dirubah dengan Undang-Undang Nomor 20 Tahun 2001 tentang Pemberantasan Tindak Pidana Korupsi dapat dilangsungkan tanpa kehadiran terdakwa (in absentia), dengan memenuhi beberapa syarat antara lain: terdakwa telah dipanggil secara sah, dan terdakwa tidak hadir di sidang pengadilan tanpa alasan yang sah.

Tanpa alasan yang sah dalam hal pemanggilan terdakwa tidak diatur secara spesifik dalam KUHAP sehingga terkait hal tersebut merupakan pertimbangan hakim semata yang menentukan mengenai sah atau tidaknya alasan-alasan terdakwa. Para majelis hakim menetapkan berdasarkan suatu pertimbangan terhadap putusan Nomor 46/Pid-SusTPK/2016/PN.Tjk bahwa pemeriksaan dipersidangan terhadap para terdakwa tanpa hadirnya para terdakwa (in absentia). Pada intinya, hakim berkeinginan agar perkara ini berlangsung cepat tanpa penundaan-penundaan yang dikarenakan tidak hadirnya terdakwa sesuai dengan asas dari peradilan.

Mengingat pentingnya menjalankan asas peradilan cepat maka Majelis Hakim memutuskan untuk membacakan putusan sidang dengan cara in absentia atau tanpa kehadiran terdakwa. Hal ini sudah sesuai dengan penjelasan Pasal 38 Ayat (1) bahwa "ketentuan dalam ayat ini dimaksudkan untuk menyelamatkan kekayaan negara, sehingga tanpa kehadiran terdakwapun, perkara dapat diperiksa oleh hakim."

Pertimbangan hakim terhadap perkara tindak korupsi di atas telah sesuai konsideran huruf c KUHAP terkait dengan penegakan HAM dikarenakan pengadilan yang memutuskan perkara tanpa hadirnya terdakwa yang pada akhirnya bahwa pengadilan merupakan sebuah lembaga atau "alat" untuk menjalankan kekuasaan negara penegakan hukum dan keadilan masyarakat.

\section{Kesimpulan}

Peradilan dengan cara in absentia dalam perkara tindak pidana korupsi sangat membantu terciptanya peradilan yang cepat dan sederhana. Kontribusi terbesar peradilan yang dilakukan dengan cara in absentia dalam dalam perkara Tindak Pidana Korupsi tidak melanggar hakhak terdakwa, hal ini dikarenakan kepada terdakwa pada setiap proses atau tahapan peradilan pidana baik sejak proses penyelidikan, penyidikan dan persidangan diberikan kesempatan untuk mengikutinya atau hadir akan tetapi terdakwa memilih untuk tidak menggunakan haknya yang diberikan oleh KUHAP dengan tidak hadir pada tahapan-tahapan tersebut. Pertimbangan hakim terhadap putusan Nomor 46/Pid-Sus-TPK/2016/PN.Tjk dengan menggunakan peradilan in absentia selain mewujudkan peradilan yang cepat dan sederhana 
juga agar tidak menimbulkan keresahan pada masyarakat dengan adanya kepastian hukum, pengembalian kerugian keuangan negara serta hukuman badan yang tepat buat pelakunya.

\section{Daftar Pustaka}

A. Buku

Adji, Indriyanto Seno. 2009. Korupsi dan Penegakan Hukum. Diadit Media, Jakarta.

Ali, Daud M. 2000. Pengantar Ilmu Hukum dan Tata Hukum Islam di Indonesia. PT Raja Grafindo Persada, Jakarta.

Efendy, Marwan. 2010. Peradilan In Absentia dan Koneksitas. PT Thimpani Phublishing, Jakarta.

Faisal Salam, Moch. 2001. Hukum Acara Pidana Dalam Teori dan Praktek. CV Mandar Maju, Bandung.

Hamzah, Andi. 1985. Pengantar Hukum Acara Pidana. Ghalia Indonesia, Jakarta.

Hartanti, Evi. 2009. Tindak Pidana Korupsi. Sinar Grafika. Edisi. Kedua, cetakan ke-3, Jakarta.

Prihartono, Dwiyanto. 2003. Sidang Tanpa Terdakwa, Dilema Peradilan In Absentia dan Hak Asasi Manusia. Pusataka Pelajar, Yogyakarta.

Yanuar, Purwaning M, 2007. Pengembalian Aset Hasil Korupsi berdasarkan Konvensi PBB Anti Korupsi 2003 dalam Sistem Hukum Indonesia. PT Alumni, Bandung.

B. Jurnal

Airlangga, Shandi Patria. "Hakikat Penguasa Dalam Negara Hukum Demokratis The Nature Of The Authorities In A Democratic Rule Of Law." Cepalo 3, no. 1, September 17, 2019: 110. https://doi.org/10.25041/cepalo.v3no1.1783.

Akli, Zul. "Peradilan In Absentia Terhadap Terdakwa Yang Belum Di-Periksa Pada Tingkat Penyidikan Dalam Perkara Tindak Pi-Dana Korupsi." REUSAM- Jurnal Ilmu Hukum. Vol. 8, May 13, 2020: 52-68. https://ojs.unimal.ac.id/index.php/reusam/article/view/2613.

Ardhyansah "Penyidikan In Absentia Dalam Penanganan Tindak Pidana Korupsi Di Indonesia (Sebuah Alternatif Penerapan Asas Peradilan Cepat)." Jurnal Idea Hukum.” Accessed August 10, 2020: 114-130. http://www.jih.fh.unsoed.ac.id/index.php/jih/article/view/135/115.

Arly, and Y Mangoli. "Eksistensi Peradilan In Absentia Dalam Hukum Acara Pidana Di Indonesia Menurut KUHAP." LEX CRIMEN. Vol. 5, April 7, 2016: 66-74. https://ejournal.unsrat.ac.id/index.php/lexcrimen/article/view/11682.

Dunggio, Haklainul, Bambang Sugiri, and Rachmad Syafa'at. "Peradilan In Absentia Bagi Pelanggar Lalu Lintas Yang Berkeadilan The Justice Of In Absentia Judicatory For Traffic Offender." Jurnal Ilmiah Pendidikan Pancasila Dan Kewarganegaraan. Vol. 4, January 6, 2020: 259-268. http://journal2.um.ac.id/index.php/jppk.

Fikri, Mohammad Ali, and Pudji Astuti. "Analisis Yuridis Penyelesaian Perkara Disersi Yang Diputus Secara In Absentia Sebelum Jangka Waktu 6 Bulan (Studi Kasus Di Pengadilan Militer Iii-12 Surabaya)." Jurnal Novum. Vol. 4, October 15, 2017: 1-7. http://www.dilmil-surabaya.go.id.

Hafidz "Sistem Pertanggungjawaban Perkara Korupsi Dalam Rangka Percepatan Penyelamatan Uang Negara." Jurnal Dinamika Hukum.” Accessed August 10, 2020: 130-145 . http://dinamikahukum.fh.unsoed.ac.id/index.php/JDH/article/view/269/261.

Jurnal Legeslasi Indonesia, Volume 7 Nomor 4 Desember 2010, Direktorat Jenderal Peraturan Perundang-Undangan Kementrian Hukum dan Hak Asasi Manusia RI.

Lasmadi, Sahuri, and M Hum. "Tumpang Tindih Kewenangan Penyidikan Pada Tindak Pidana Korupsi Dalam Perspektif Sistem Peradilan Pidana." INOVATIF Jurnal Ilmu Hukum. Vol. 2, 2010. https://online-journal.unja.ac.id/jimih/article/view/200.

Laurance Hasiholan Pasaribu, Olan, Iman Jauhari, and Elvi Zahara Lubis. "Kajian Yuridis Terhadap Putusan Bebas Tindak Pidana Korupsi (Studi Kasus Pada Pengadilan Negeri 
Medan).” JURNAL MERCATORIA. Vol. 1, 2008: 130-140. http://ojs.uma.ac.id/index.php/mercatoria/article/view/627.

Utomo "Pembuktian Dakwaan Oditur Militer Dalam Pemeriksaan Secara In Absentia Pada Persidangan Perkara Desersi Di Masa Damai." Verstek." Accessed August 10, 2020: 146156. https://jurnal.uns.ac.id/verstek/article/view/38387/25424.

Sahlan, Mohammad, Biro Hukum, Dan Organisasi, Kementerian Kelautan, Perikanan Gedung, and Mina Bahari. "Unsur Menyalahgunakan Kewenangan." Jurnal Hukum IUS QUIA IUSTUM. Vol. 23, October 17, 2016: 193-271. http://news.detik.com/berita/2873765/uuadministrasi-pemerintahan-dinilai-mengudeta-pem.

Suhariyanto, "Budi A, and Cempaka Putih Timur Jakarta. "Progressivity of Criminal Decision on Corporate Actors Corruption." Disetujui Diterbitkan. Vol. 16, June 1: 201-213, 2016. https://ejournal.balitbangham.go.id/index.php/dejure/article/view/58.

Sukardi, Irma. 2012. Bantuan Timbal Balik dalam Masalah Pidana (Mutual Legal Assistance) dalam Perampasan Aset Tindak Pidana Korupsi Berdasarkan Undang-Undang Nomor 1 Tahun 2006 tentang Bantuan Timbal Balik dalam Masalah Pidana. Tesis Pasca FH UI, Jakarta.

Suriady Harianja, "Peradilan In Absentia Pada Perkara Tindak Pidana Korupsi Dalam Perspektif HAM Terdakwa," UNNES Law Journal. Vol. 2, no. 1 (2013): 36-43 https://journal.unnes.ac.id/sju/index.php/ulj/article/view/2903/2686.

Warmadewa, Universitas, and Indonesia Denpasar-Bali. "A A Made Yuda Dwi Hendrata*, A A Sagung Laksmi Dewi Dan I Nengah Laba." Jurnal Analogi Hukum 1, no. 1 (December 17, 2019): 1-5. https://doi.org/10.22225/.1.1.1448.1-5.

Wignjosoebroto, Soetandyo Masalah Metodelogik dalam Penelitian Hukum Sehubungan Dengan Keragaman Pendekatan Konseptualnya, Makalah pada Pelatihan Metodelogi Penelitian Ilmu Sosial, FH Undip, Semarang, 14-15 Mei 1999.

Wibowo, Edy. "Peranan Hakim dalam Pencegahan dan Pembrantasan Korupsi". Varia Pradilan, Majalah Hukum Tahun XXIV No. 279 Februari 2009.

Wulansari, Eka Martiana. "Mekanisme Pengembalian Aset Hasil Tindak Pidana Korupsi". Jurnal Legeslasi Indonesia, Volume 7 Nomor 4 Desember 2010, Direktorat Jenderal Peraturan Perundang-Undangan Kementrian Hukum dan Hak Asasi Manusia RI.

Yasser, Bram Mohammad. "Pengujian Unsur Penyalahgunaan Wewenang Pada Peradilan Tata Usaha Negara Dalam Kaitannya Dengan Tindak Pidana Korupsi." Soumatera Law Review 2, no. 1 (May 1, 2019): 1-24. https://doi.org/10.22216/soumlaw.v2i1.3558.g1352. 